\title{
Physiological responses of seeds from full-sib guava families to different substrate temperatures
}

\author{
Mariana Quintas Maitan ${ }^{1}$, Alexandre Pio Viana ${ }^{2}$, Henrique Duarte Vieira ${ }^{3}$, \\ Carla Caroline Amaral da Silva ${ }^{4}$, Daniele Lima Rodrigues ${ }^{5}$, Lucas Souza da Silva Leal ${ }^{6}$
}

\begin{abstract}
Guava is an important fruit in Brazil and worldwide. However, research has yet to advance on its breeding and seed technology, an essential factor for the development of productive genotypes with germination potential which would support the continuity of breeding programs. In search of a methodology for routine analysis testing of guava seeds under genetic control, this study examined the effect of temperature and substrate on the germination of guava seeds from full-sib families. The experiment was laid out in a completely randomized design with a $5 \times 4$ factorial arrangement consisting of the combination of five temperatures $(25,30,35,20-30$ and $25-35^{\circ} \mathrm{C}$ ) and four substrates (paper roll, on-paper, in-sand and on-sand), with eight replicates of 50 seeds. Germination, germination speed index and live ungerminated seeds were evaluated. The alternating temperatures of $20-30$ and $25-35^{\circ} \mathrm{C}$ and the paper roll, on-paper and in-sand substrates are adequate conditions for germination tests with guava seeds.
\end{abstract}

Index terms: Psidium guajava, germination, germination speed index.

\section{Respostas fisiológicas de sementes de famílias de irmãos completos de goiabeira a diferentes substratos de temperaturas}

Corresponding author: marianaquintasm@gmail.com

Received:December 18, 2019 Accepted: May 27, 2020

Copyright: All the contents of this journal, except where otherwise noted, is licensed under a Creative Commons Attribution License.
Resumo -A goiaba é uma fruta de importância no Brasil e no mundo. No entanto, as pesquisas ainda precisam avançar na área de melhoramento genético e na tecnologia de sementes, que é fator fundamental na busca de novos genótipos produtivos e com potencial germinativo, dando apoio à continuidade dos programas de melhoramento. Na busca de metodologia para teste de análise de rotina de sementes de goiaba sob controle genético, objetivou-se avaliar o efeito da temperatura e do substrato na germinação de sementes de goiaba oriundas de famílias de irmãos completos. $\mathrm{O}$ delineamento experimental utilizado foi o inteiramente casualizado, em esquema fatorial $5 \times 4$, constituído pela combinação de cinco temperaturas $\left(25 ; 30 ; 35 ; 20-30\right.$ e $\left.25-35^{\circ} \mathrm{C}\right)$ e quatro substratos (rolo de papel; sobre papel; entre areia e sobre areia), com oito repetições de 50 sementes. Foram avaliadas a germinação, o índice de velocidade de germinação e as sementes não germinadas vivas. As temperaturas alternadas de $20-30$ e $25-35^{\circ} \mathrm{C}$ e os substratos rolo de papel, sobre papel e entre areia são as condições adequadas para condução de testes de germinação com sementes de goiaba. Termos para Indexação: Psidium guajava; germinação; índice de velocidade de germinação.

${ }^{1}$ Doctorate in Program Plant Production - Laboratório de Melhoramento Genético Vegetal, Centro de Ciências e Tecnologias Agropecuárias, State University of Norte Fluminense Darcy Ribeiro, Campos dos Goytacazes - RJ, Brazil. E-mail: marianaquintasm@gmail.com (0RCID 0000-0003-1989-0771) ${ }^{2}$ D.Sc., Associate Professor, Laboratório de Melhoramento Genético Vegetal, Centro de Ciências e Tecnologias Agropecuárias, State University of Norte Fluminense Darcy Ribeiro, Campos dos Goytacazes - RJ, Brazil. E-mail: pirapora@uenf.br (ORCID 0000-0002-2475-4910)

${ }^{3}$ D.Sc., Associate Professor, Laboratório de Fitotecnia, Centro de Ciências e Tecnologias Agropecuárias, State University of Norte Fluminense Darcy Ribeiro, Campos dos Goytacazes - RJ, Brazil. E-mail: henrique@uenf.br (ORCID 0000-0002-1933-3249)

${ }^{4} \mathrm{MSc}$ in Program in Plant Production - Laboratório de Fitotecnia, Centro de Ciências e Tecnologias Agropecuárias, State University of Norte Fluminense Darcy Ribeiro, Campos dos Goytacazes - RJ, Brazil. E-mail: carla.carolineas@gmail.com (ORCID 0000-0002-1723-8942)

${ }^{5}$ D.Sc., Adjunct Professor, Centro de Ciências Agrárias, Naturais e Letras, Universidade Estadual da Região Tocantina do Maranhão, Estreito Maranhão, Brazil, E-mail: daniele.rodrigues@uemasul.edu.br (ORCID 0000-0002-9008-3705)

${ }^{6}$ Agronomy Student Laboratório de Melhoramento Genético Vegetal, Centro de Ciências e Tecnologias Agropecuárias, State University of Norte Fluminense Darcy Ribeiro, Campos dos Goytacazes - RJ, Brazil. E-mail: lucas.souzaleal@gmail.com (ORCID 0000-0003-4272-339X) 


\section{Introduction}

Guava (Psidium guajava L.) is an important fruit for Brazil and worldwide, due both to its fresh consumption and the great demand by the sweets industry. Brazil is one of the largest producers of red guava in the world.

Guava breeding programs are aimed at increasing yield (ALMEIDA et al., 2019) or developing resistance to some disease (GOMES et al., 2017). The crop is propagated in commercial orchards via cuttings, which are used to produce seedlings that allow the formation of uniform orchards (SINGH, 2007). However, in the breeding of this crop, plants are multiplied using seeds to ensure greater genetic variability (PEREIRA; KAVATI, 2011).

Due to its high allogamy rate, guava is highly heterozygous (ALVES; FREITAS, 2007). When full-sib families are obtained by crosses in pairs, the homozygosity of the population is increased. Uniform inbred lines can be obtained from self-pollination processes, considering that this process results in decreased genetic variance within lines and increased variance between lines (BORÉM et al., 2017). The main test used to evaluate seed quality is the germination test, which is followed by seed vigor tests. Nevertheless, for many fruit crops, including guava, information for routine germination analysis testing is not provided in the International Rules for Seed Testing. Through a set of procedures, these rules aim to analyze seed quality and standardize such procedures (BRASIL, 2009).

Because germination is regulated by the interaction between seed physiological processes and environmental conditions, it differs across plant species. A successful germination process requires favorable water, temperature, light, oxygen and substrate conditions (MONDO et al., 2010).

Temperature exerts a great influence on the germination process, interfering with water absorption by the seeds; chemical reactions that regulate metabolism; and the speed, percentage and uniformity of germination (CARVALHO; NAKAGAWA, 2012; MARCOS FILHO, 2015). To define the ideal temperature for germination, it is important that the seeds be able to express their full physiological potential in the formation of normal seedlings (BRANCALION et al., 2008).

Another factor of great relevance in the germination process is the choice of the substrate, which should exhibit a good relationship between water availability and aeration. The ideal substrate should facilitate the count and evaluation of seedlings, considering also the size, shape and requirements of the seed that will be analyzed (BRASIL, 2009).
Therefore, the present study was conducted to determine the ideal substrate and temperature for germinating guava seeds from full-sib families, according the International Rules for Seed Testing (BRASIL, 2009).

\section{Material and Methods}

The seeds used in this study originated from fruits from the orchard of the Breeding Program of the Universidade Estadual Norte Fluminense Darcy Ribeiro.

Fifty ripe fruits from full-sib families were harvested at random in March 2018. The seeds were removed manually and washed in running water over a steel-mesh sieve by the rubbing method. Once extracted, the seeds were laid on paper towel to dry for $48 \mathrm{~h}$, at room temperature. Subsequently, the water content of the seeds was determined by oven-drying at $105 \pm 3{ }^{\circ} \mathrm{C}$, for $24 \mathrm{~h}$, using four replicates of three grams of seeds. Thousandseed weight was determined by weighing eight replicates of 1000 seeds on a scale with four decimal places. Both procedures were undertaken in accordance with the Rules for Seed Testing (BRASIL, 2009).

The tests were conducted in a germination chamber set to provide a photoperiod of $8 \mathrm{~h}$. Five temperatures $\left(25^{\circ} \mathrm{C}, 30^{\circ} \mathrm{C}, 35^{\circ} \mathrm{C}\right.$ and the alternating temperatures of 20-30 ${ }^{\circ} \mathrm{C}$ and $25-35^{\circ} \mathrm{C}$ ) and four germination substrates (paper roll, on-paper, in-sand and on-sand) were tested. (BRASIL, 2009).

For the paper roll substrate, two sheets of germination paper were moistened with distilled water at the ratio of 2.5 times the weight of the non-moistened paper and arranged in a roll (BRASIL, 2009). For the onpaper substrate, each of the eight replicates of 50 seeds was placed in transparent acrylic boxes measuring $11 \times 11 \times 3$ $\mathrm{cm}$. These contained two sheets of paper, which were cut, sterilized and moistened with distilled water at the ratio of 2.5 times the weight of the dry paper (BRASIL, 2009).

For the in-sand and on-sand substrates, plastic boxes measuring $11 \times 11 \times 5 \mathrm{~cm}$ were used. The substrates were moistened with distilled water until reaching $60 \%$ of field capacity (BRASIL, 2009). The 50 seeds of the eight replicates were deposited at a depth of $1 \mathrm{~cm}$, and those to be used for the on-sand treatment were simply laid on the substrate.

The effect of substrates and temperatures was evaluated by germination tests, whereby the seeds were counted on alternate days and only the seedlings with an aerial part $1 \mathrm{~cm}$ long were considered a germinated seed. Germination speed index (GSI) was also determined, by using the formula described by Maguire (1962) after the end of the 27-day test, when germination, the number of live ungerminated seeds and the number of dead seeds stabilized. To identify live seeds among those that did not germinate, they were subjected to the tetrazolium test. This 
procedure consisted of immersing ungerminated seeds sectioned lengthwise with a scalpel in aqueous solution of tetrazolium bromide at a concentration of $1 \%$ for $4 \mathrm{~h}$, in a closed container without incident light, to stain the live tissues (BRASIL, 2009).

The experiment was laid out in a completely randomized design with a $5 \times 4$ factorial arrangement (temperatures $\times$ substrates) with 50 seeds and eight replicates. Means were compared by Tukey's test at the 5\% probability level, using Sisvar (System for Analysis of Variance) software (FERREIRA, 2008).

\section{Results and Discussion}

The guava seeds showed a water content of approximately $11.5 \%$ and a 1,000 -seed weight of $14.40 \mathrm{~g}$. The interaction between temperatures and substrates was significant for all analyzed variables (Table 1).

Table 1. Summary of analysis of variance for germination test (G), germination speed index (GSI) and live ungerminated seeds (LUS) as a percentage of guava seeds at five temperatures in the four substrates.

\begin{tabular}{ccccc}
\hline & \multicolumn{4}{c}{ Mean square } \\
\hline Source of variation & DF & G & GSI & LUS \\
\hline Replicate & 7 & $45.796429^{*}$ & $3.367292^{*}$ & $95.996429^{*}$ \\
Substrate & 3 & $14434.691667^{*}$ & $607.802420^{*}$ & $11205.091667^{*}$ \\
Temperature & 4 & $27602.937500^{*}$ & $1139.627735^{*}$ & $27990.537500^{*}$ \\
Substrate $\times$ Temperature & 12 & $5017.920833^{*}$ & $218.150594^{*}$ & $2815.487500^{*}$ \\
Residue & 133 & 42.954323 & 3.368795 & 90.003947 \\
\hline Coefficient of variation (\%) & & 16.26 & 23.54 & 17.75 \\
\hline
\end{tabular}

Significant at $5 \%$ probability by the $\mathrm{F}$ test $(\mathrm{P}<0.05)$; $\mathrm{DF}=$ degrees of freedom.

According to the guava seed germination test, at the alternating temperatures of $20-30{ }^{\circ} \mathrm{C}$ and $25-35{ }^{\circ} \mathrm{C}$, germination values higher than $90 \%$ were found in the paper roll, on-paper and in-sand substrates, as opposed to the on-sand substrate (Figure 1). However, at the constant temperatures of 25,30 and $35^{\circ} \mathrm{C}$, the best germination substrate was in-sand, although the germination percentage was lower than $40 \%$ (Figure 1).

These results are similar to those found by Alves et al. (2015), who observed that guava seeds reach higher germination values at the alternating temperatures of 20 $30{ }^{\circ} \mathrm{C}$ in the paper roll, on-paper, on-sand and in-sand substrates, when compared with the constant temperatures of 20,25 and $30{ }^{\circ} \mathrm{C}$. In this study, the same was not observed with the on-sand substrate, due to the difficulty in maintaining seed moisture. Other authors, such as Pereira and Andrade (1994), examined the germination of $P$. guajava seeds and observed that the alternating temperatures of $20-30{ }^{\circ} \mathrm{C}$ and $15-35{ }^{\circ} \mathrm{C}$ provided higher germination values than the constant temperatures of 25 and $30{ }^{\circ} \mathrm{C}$ using the paper roll, vermiculite and on-paper substrates.

Freitas et al. (2012) also conducted germination experiments with guava seeds and observed higher germination values at the alternating temperatures of 20-30 ${ }^{\circ} \mathrm{C}$ as compared with the constant temperatures of 20 and $30^{\circ} \mathrm{C}$, using the on-paper substrate. Those authors used root emergence as a trait for evaluation in the germination test. This germination assessment methodology likely contributed to the marked increase in germination percentage.

Sugahara and Takaki (2004) stated that guava seeds exhibit higher germination percentages when subjected to alternating temperatures. The authors induced germination under light and dark conditions and observed that, in the latter condition, a $5{ }^{\circ} \mathrm{C}$ variation was sufficient to induce germination, but a $10^{\circ} \mathrm{C}$ variation caused an even greater increase in germination percentage under white light. However, the highest germination values were seen in the range of $15^{\circ} \mathrm{C}$. This result confirms the efficiency of alternating temperatures in increasing germination rate in guava seed.

According to Bewley and Black (1982), alternating temperatures cause the seed integument to expand and retract, resulting in small cracks that allow the entry of water into the seed. The seed germination process is complex and involves reactions and phases which are directly affected by temperature, altering the water absorption speed and metabolic reactions that make reserves available for seedling development (NAKAGAWA, 2012; MARCOS-FILHO, 2015). 


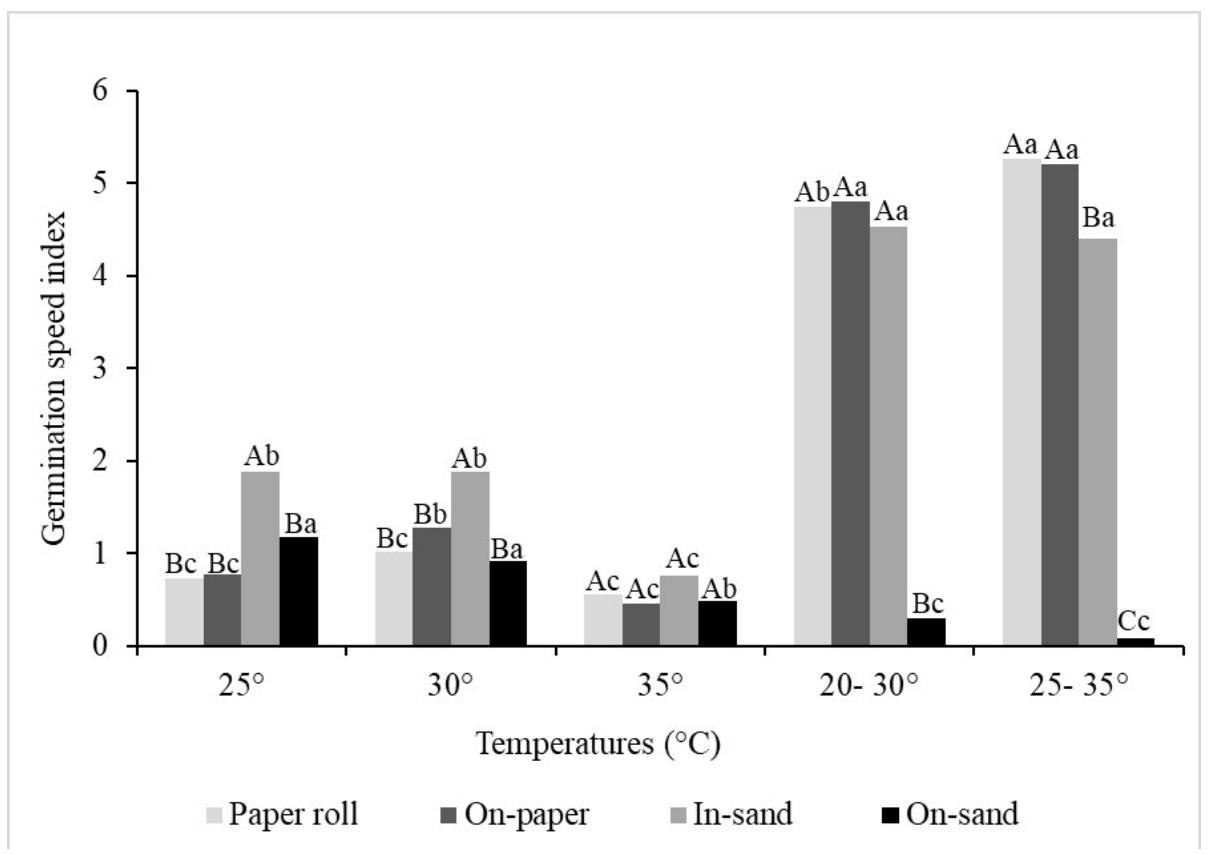

Figure 1. Germination (\%) of guava seeds as a function of temperatures and substrates.

-Means followed by the same letter do not differ statistically from each other. Uppercases letters compare substrates and lowercase letters compare temperatures, by Tukey's test at $\mathrm{P}<0.05$.

Temperature changes allow enzymes, proteins, promoting and inhibiting substances, membrane permeability and other functions to operate at different temperature peaks. Thus, they induce alterations in membrane permeability and in enzymes acting in the germination process. Lower temperatures accelerate the activity of some enzymes, but can also reduce metabolic activity (CORBINEAU, 2008; RIX et al., 2015).

The seed germination process mobilizes nutrient reserves in the seeds through enzymes, especially those that degrade carbohydrates and cellulose (BHUSHAN et al., 2013). Guava seeds have a higher cellulose content which tends to decrease with germination and which is consumed together with starch. The main roles of cellulase are to digest the cell wall, enabling cell dissolution for radicle emergence, and to produce reserve carbohydrates to be used in seedling growth (LING et al., 2017). For this entire process to take place, ideal light, temperature, oxygen and water conditions must be present.

Because the germination process is closely related to the supply of water to the seeds, the substrate to be used must meet this requirement. In the present study, the best substrates were paper roll, on-paper and in-sand, especially at the alternating temperatures of $20-30^{\circ} \mathrm{C}$ and $25-35^{\circ} \mathrm{C}$. Those substrates provided greater water availability to the seeds, which resulted in higher germination values (Figure 1). Some studies investigating germination in $P$. guajava seeds presented similar results. Pereira and Andrade (1994) observed that, in the experimental conditions used in their study, sand was the best substrate for the germination of guava seeds. In contrast, Freitas et al. (2012) concluded that paper and the commercial substrates
Bioplant and Plantmax were superior for the germination of the same species. Alves et al. (2015) observed that the best substrates for germination of guava seeds were paper roll or sand, which are very similar results as compared with those obtained in the current study.

The on-sand substrate provided less water to the seeds, considerably reducing germination. This was due to the smaller contact surface between the seed and the sand grains, which hindered water absorption by the seed. Therefore, despite being a possible indication by the Rules of Seed Testing (BRASIL, 2009), this substrate is not recommended for the germination of guava seeds in this study, mainly at alternating temperatures (Figure 1).

For the alternating temperatures of $25-35^{\circ} \mathrm{C}$, the highest germination speed indices (GSI) were obtained with the paper roll and on-paper substrates: 5.26 and 5.20 , respectively. For the alternating temperatures of 20-30 ${ }^{\circ} \mathrm{C}$, the result was statistically equal for the paper roll, on-paper and in-sand substrates, ranging from 4.80 to 4.43. However, at the constant temperatures of 25 and $30^{\circ} \mathrm{C}$, GSI was higher only for the in-sand substrate $(1.88$ at both temperatures), differing from the other substrates. For the temperature of $35^{\circ} \mathrm{C}$, no difference was detected between the analyzed substrates, since this temperature severely affected seed germination percentage, which was less than $18 \%$ in all substrates (Figure 2). 


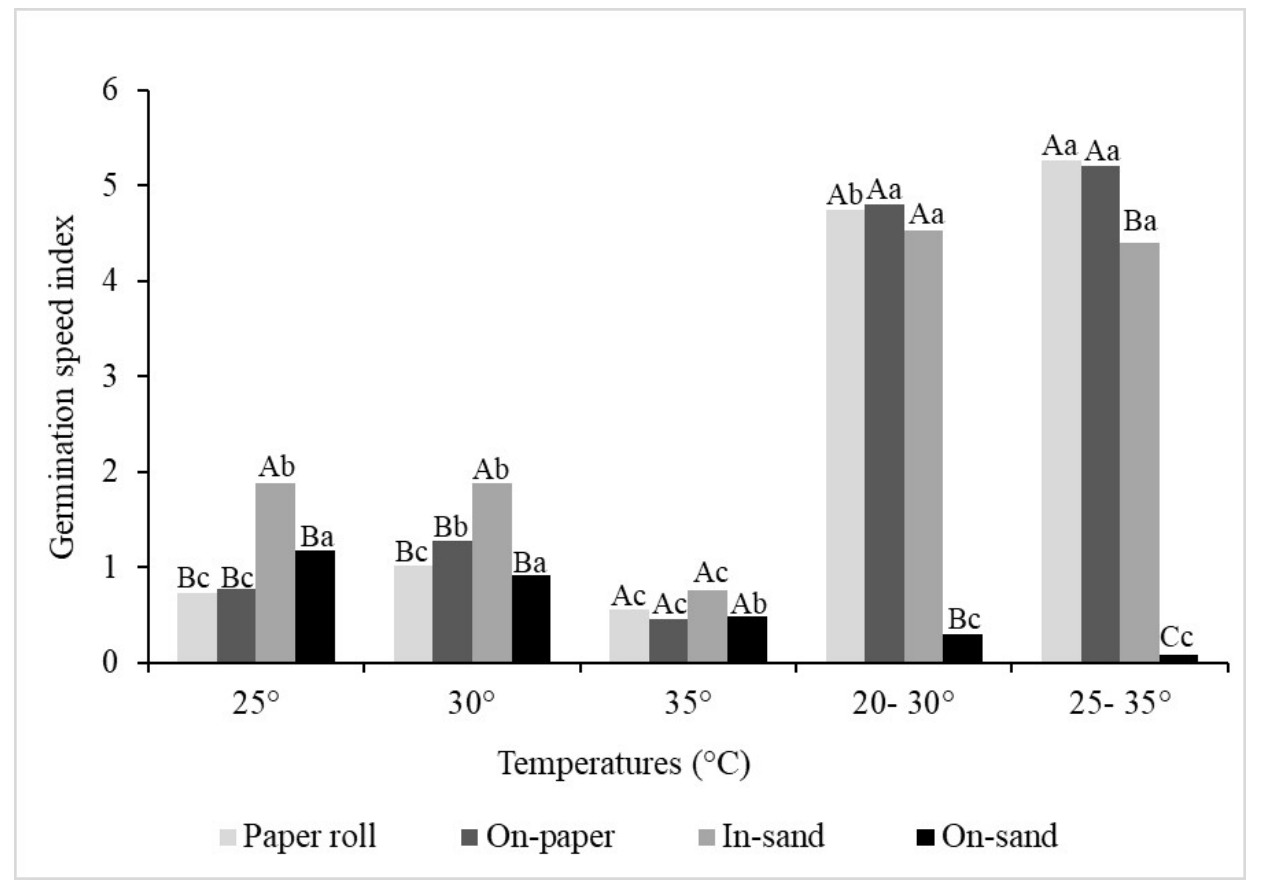

Figure 2. Germination speed index of guava seeds as a function of temperatures and substrates.

-Means followed by the same letter do not differ statistically from each other. Uppercases letters compare substrates and lowercase letters compare temperatures, by Tukey's test at $\mathrm{P}<0.05$.

The germination test lasted 27 days, when the number of germinated seeds stabilized. For the temperature of $25{ }^{\circ} \mathrm{C}$, germination began at 13 days of testing for the paper roll, on-paper and in-sand substrates. At the temperatures of 30 and $35^{\circ} \mathrm{C}$, germination started at 15 days of testing for all substrates.

At the alternating temperatures of $20-30{ }^{\circ} \mathrm{C}$, in the paper roll and on-paper substrates, the seeds started to germinate at 15 days. Those set to germinate at the temperatures of $25-35^{\circ} \mathrm{C}$ started germination at 11 days in the paper roll and on-paper substrates after the start of the test. These results demonstrate that guava seeds start to germinate earlier at the alternating temperatures of 25-35 ${ }^{\circ} \mathrm{C}$ and with those substrates.

According to Freitas et al. (2012), the alternating temperatures of $20-30{ }^{\circ} \mathrm{C}$ provided the fastest germination speeds in guava seeds on the paper substrate. Likewise, Alves et al. (2015) obtained the best GSI results in guava seeds using the alternating temperatures of $20-30{ }^{\circ} \mathrm{C}$ in the paper roll, on-paper and on-sand substrates. Gentil et al. (2018) studied Psidium friedrichsthalianum and obtained higher GSI and shorter germination times at the constant temperatures of 20 and $25^{\circ} \mathrm{C}$. However, the authors did not test alternating temperatures, which emphasizes the importance of associating the effect of different genotypes on the obtained responses, in this type of study.
At the alternating temperatures of $20-30{ }^{\circ} \mathrm{C}$ and $25-35{ }^{\circ} \mathrm{C}$, the results for germination on paper roll, on paper and in sand were higher than those obtained on sand. The same was true for GSI, except for the in-sand substrate, whose response was lower than that shown by the on-paper substrate, yet superior to that obtained with the on-sand treatment (Figures 1 and 2).

At the end of the test, all ungerminated seeds from all treatments were transferred to germination chambers with temperature set to $25-35{ }^{\circ} \mathrm{C}$, using paper roll as a substrate, for 15 days. The seeds in the treatments involving the temperatures of 25,30 and $35{ }^{\circ} \mathrm{C}$ reached germination values higher than $70 \%$, and so did those at the temperatures of $20-30{ }^{\circ} \mathrm{C}$ and $25-35{ }^{\circ} \mathrm{C}$ on sand, suggesting that they were in a state of dormancy (Figure 3) (CARVALHO; NAKAGAWA, 2012). 


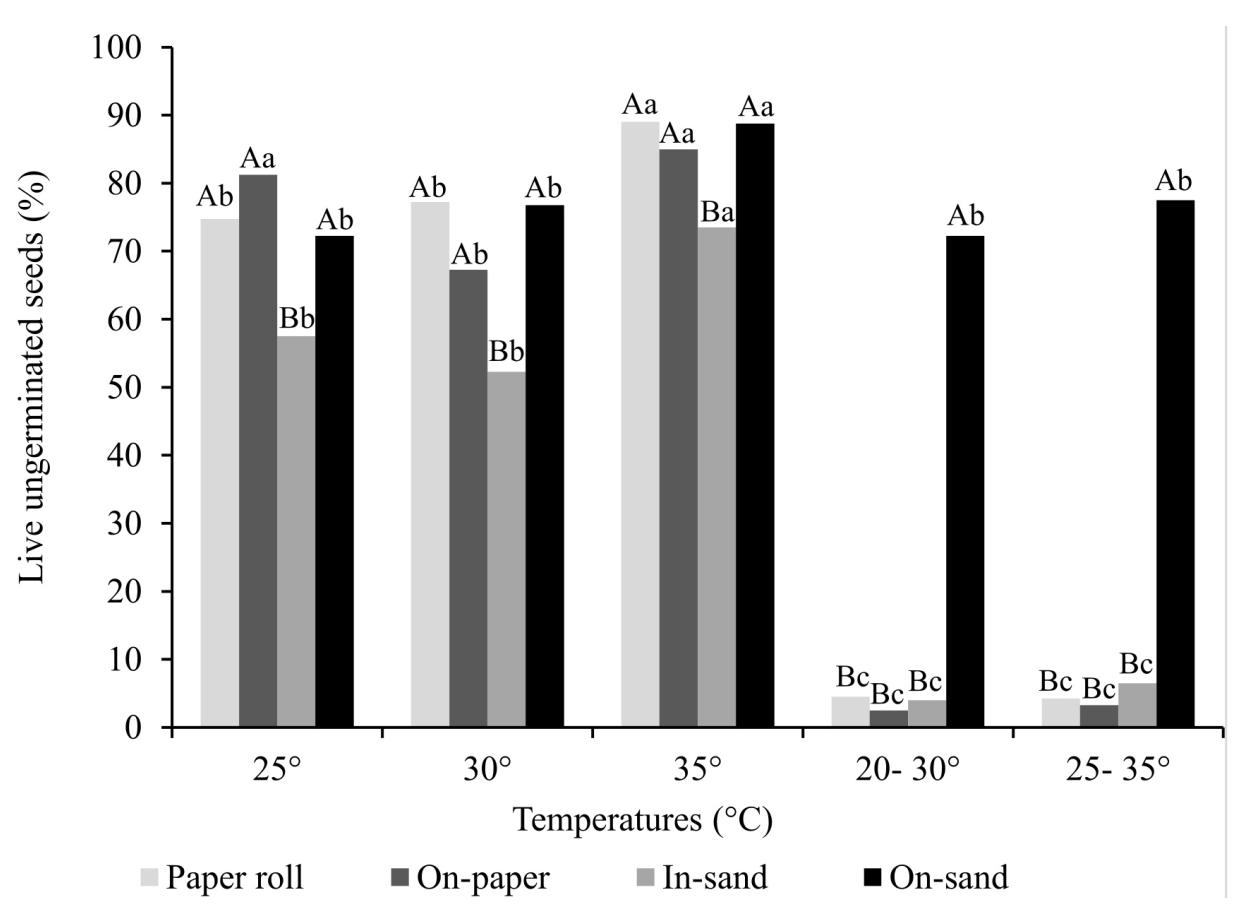

Figure 3. Live ungerminated seeds (\%) of guava as a function of temperatures and substrates.

-Means followed by the same letter do not differ statistically from each other. Uppercases letters compare substrates and lowercase letters compare temperatures, by Tukey's test at $\mathrm{P}<0.05$.

Germination is regulated by the interaction between seed physiological stage and environmental conditions, and each plant species responds differently. However, for the process to occur, water, temperature, light and oxygen must be available (MONDO et al., 2010). Of those factors, temperature directly interferes with all biochemical reactions and physiological processes, which will in turn influence germination speed and percentage (CARVALHO; NAKAGAWA, 2012; MARCOS FILHO, 2015).

Most of the seeds under constant temperatures were not able to conclude phase II, because, in addition to water availability, temperature is a crucial factor for them to reach the end of this phase (BEWLEY et al., 2013). This fact may be related to oxygen availability, since, at temperatures above $25^{\circ} \mathrm{C}$, oxygen becomes less water-soluble, with small quantities reaching the embryo. Another important factor is that high temperatures trigger thermal stress in the embryo and favor seed deterioration (ZUCARELI et al., 2009). The substrate was another factor altered by the temperature change, since all seeds were arranged on paper roll, which increased the contact area between seed and substrate, greatly affecting germination speed and complete germination (CARVALHO; NAKAGAWA, 2012).

When the ungerminated seeds were transferred to the paper roll substrate and kept at the temperatures of $25-35{ }^{\circ} \mathrm{C}$, they left this dormancy state, completed phase II and started phase III, thus concluding the germination process. The ideal temperature for the germination of seeds of a given species should be defined as the maximum potential of germination and formation of normal seedlings, since the water absorption speed and biochemical reactions will be favored (BRANCALION et al., 2008; MARCOS FILHO, 2015).

At the alternating temperatures of $20-30^{\circ} \mathrm{C}$ and 25 $35^{\circ} \mathrm{C}$, the on-sand substrate showed a higher number of live seeds that did not germinate, as this substrate proved to be inefficient for the germination of guava seeds at these temperatures, but did not cause death of the majority of the seeds. The same occurred at the fixed temperatures of 25,30 and $35^{\circ} \mathrm{C}$, in which the highest numbers of ungerminated live seeds were found in the paper roll, onpaper and on-sand substrates, which showed the worst germination responses (Figure 3).

\section{Conclusion}

The germination test for guava seeds should be carried out at the alternating temperatures of $20-30{ }^{\circ} \mathrm{C}$ or $25-35{ }^{\circ} \mathrm{C}$ using the paper roll, on-paper or in-sand substrates

\section{Acknowledgements}

This study was financed in part by the Coordenação de Aperfeiçoamento de Pessoal de Nível Superior - Brasil (CAPES) -Finance Code 001 and Fundação de Amparo à Pesquisa do Estado do Rio de Janeiro (FAPERJ). 


\section{References}

ALMEIDA, C.L.P.; VIANA, A.P.; SANTOS, E.A.; QUINTAL, S.S.R. Repetibility in guava: how many evaluations is necessary for selection the best guava tree. Functional Plant Breading Journal, Campos dos Goytacazes, v.1, n.2, p.51-60, 2019.

ALVES, C.Z.; SILVA, J.B.; CÂNDIDO, A.C.S. Metodologia para a condução do teste de germinação em sementes de goiaba. Revista Ciência Agronômica, Fortaleza, v.46, n.3, p.615-621, 2015.

ALVES, J.E.; FREITAS, B.M. Requerimentos de polinização da goiabeira. Ciência Rural, Santa Maria, v.37, n.5, p.1281-1286, 2007.

BEWLEY, J.D.; BLACK, M. Physiology and biochemistry of seed in relation to germination: viability, dormancy and environmental control. Berlin: Springer-Verlag, 1982.375p.

BEWLEY, J.D.; BRADFORD, K.J.; HILHORST, H.W.M.; NONOGAKI, H. Seeds: physiology of development germination and dormancy. New York: Springer, 2013. $392 p$.

BHUSHAN, B.; PAL, A.; SINGH, A. Effect of lead on protein dissolution and phosphate mobilization in germinating oat [Avena sativa (L.) cv. HJ-8] seeds. Indian Journal of Agricultural Research, Haryana, v.47, p.402410, 2013.

BORÉM, A.; MIRANDA, G.V.; FRITSCHE-NETO, R. Melhoramento de plantas. 7.ed. Viçosa: Ed. UFV, 2017. 543p.

BRANCALION, P.H.S.; NOVEMBRE, A.D.L.C.; RODRIGUES, R.R.; CHAMMA, H.M.C.P. Efeito da luz e de diferentes temperaturas na germinação de sementes de Heliovarpus pipayanensis L. Revista Árvore, Viçosa, MG, v.32, n.2, p.225-232, 2008.

BRASIL. Ministério da Agricultura, Pecuária e Abastecimento. Regras para análise de sementes. Brasília, DF: Mapa/ACS, 2009. 395p.

CARVALHO, N.M.; NAKAGAWA, J. Sementes: ciência, tecnologia e produção. 5.ed. Jaboticabal: FUNEP, 2012. $588 \mathrm{p}$.

CORBINEAU, F. Markers of seed quality: from present to future. Seed Science Research, Wallingford, v.22, p.61-68, 2012.
FERREIRA, D.F. SISVAR- um programa para análises e ensino de estatística. Revista Científica Symposium, Lavras, v.6, p.36-41, 2008.

FREITAS, A.R.; LOPES, J.C.; MACIEL, K.S.; VENÂNCIO, L.P. Germinação de sementes de goiaba em função dos substratos e regime de temperaturas. Enciclopédia Biosfera, Jandaia, v.8, n.14, p.615, 2012.

GENTIL, D.F.O.; FERREIRA, S.A.N.; REBOUÇAS, E.R. Germination of Psidium friedrichsthalianum (O. Berg) Nied. seeds under different temperature and storage conditions. Journal of Seed Science, Londrina, v.40, n.3, p.246-252, 2018.

GOMES, V.M.; RIBEIRO, R.M.; VIANA, A.P.; SOUZA, R.M.; SANTOS, E.A.; RODRIGUES, D.L.; ALMEIDA, O.F. Inheritance of resistance to Meloidogyne enterolobii and individual selection in segregating populations of Psidium spp. European Journal of Plant Pathology, Dordrecht, v.148, p. 699-708, 2017.

LING, C.X.; CHANG, Y.P. Valorizing guava (Psidium guajava L.) seeds through germination-induced carbohydrate changes. Journal Food Science and Technology, Mysore, v.54, n.7, p.2041-2049, 2017.

MAGUIRE, J.D. Speed of germination aid in selection and evaluation for seeding emergence and vigor. Crop Science, Madison, v.2, n.2, p.76-177, 1962.

MARCOS FILHO, J. Fisiologia de sementes de plantas cultivadas. 2.ed. Londrina: ABRATES, 2015. 660p.

MONDO, V.H.V.; CARVALHO, S.J.P.; DIAS, A.C.R.; MARCOS FILHO, J. Efeito da luz e temperatura na germinação de sementes de quatro espécies de plantas danificadas pelo gênero Digitaria. Revista Brasileira de Sementes, Londrina, v.32, n.1, p.131-137, 2010.

PEREIRA, F.M.; KAVATI, R. Contribuição da pesquisa científica brasileira no desenvolvimento de algumas frutíferas do clima subtropical. Revista Brasileira de Fruticultura, Jaboticabal, v.33, n.1, p.92-108, 2011.

PEREIRA, T.S.; ANDRADE, A.C.S. Germinação de Psidium guajava L. e Passiflora edulis Sims: efeito da temperatura, substrato e morfologia do desenvolvimento pós-seminal. Revista Brasileira de Sementes, Londrina, v.16, n.1, p.58-62, 1994.

RIX, K.D.; GRACIE, A.J.; POTTS, B.M.; BROWN, P.H.; GORE, P.L. Genetic control of Eucalyptus globulus seed germination. Annals of Forest Science, Paris, v.72, n.4, p.457-467, 2015. 
SINGH, G. Desenvolvimento recente na produção de goiaba. Acta Horticulturae, The Hague, n.735, p.161176, 2007.

SUGAHARA, V.Y.; TAKAKI, M. Effect of light and temperature on seed germination in guava (Psidium guajava L. - Myrtaceae). Seed Science and Technology, Mysore, v.32, n.3, p.759-764, 2004.
ZUCARELI, V.; FERREIRA, G.; AMARO, A.C.E.; ARAÚJO, F.P. Fotoperíodo, temperaturae reguladores vegetais na germinação de sementes de Passiflora cincinnata Mast. Revista Brasileira de Sementes, Londrina, v.31, p.106-114, 2009. 


\section{Erratum of article:}

Maitan, Mariana Quintas, Viana, Alexandre Pio, Vieira, Henrique Duarte, Silva, Carla Caroline Amaral da, Rodrigues, Daniele Lima, \& Leal, Lucas Souza da Silva. (2020). Physiological responses of seeds from full-sib guava families to different substrate temperatures. Rev. Bras. Frutic., 42(6): e-278. DOI: 10.1590/0100-29452020278.

In the page 4, Figure 1, where it reads:

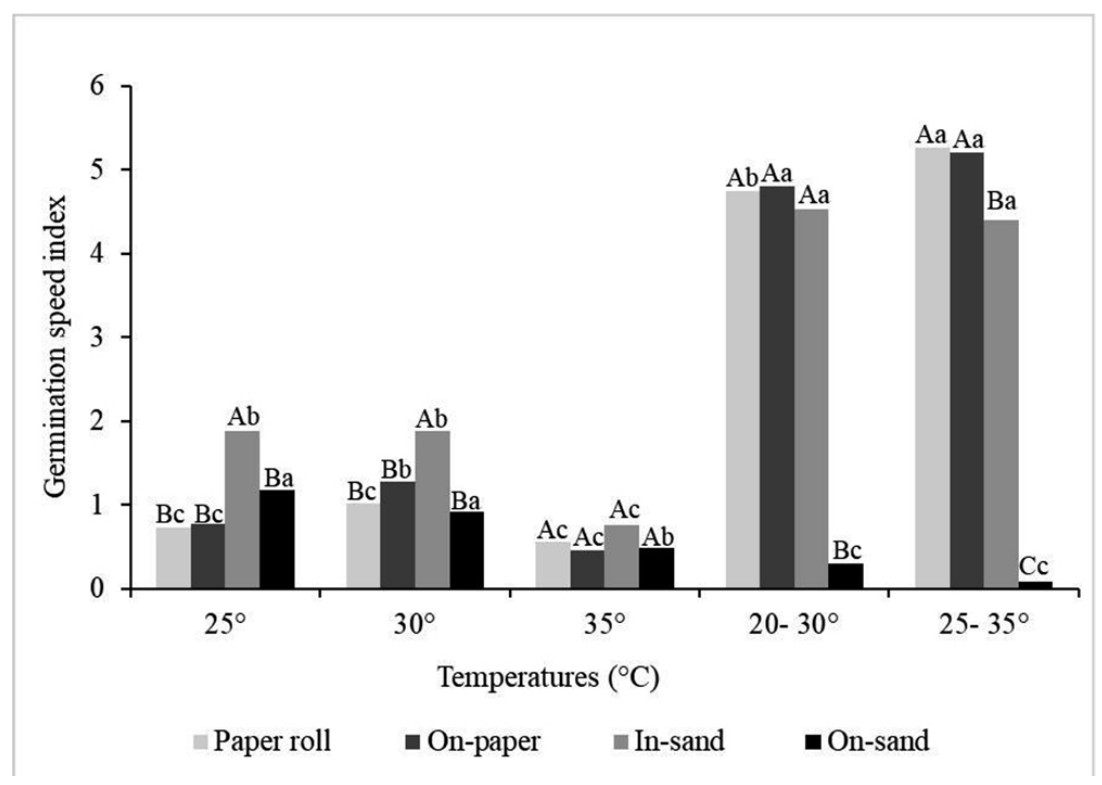

Figure 1. Germination (\%) of guava seeds as a function of temperatures and substrates. -Means followed by the same letter do not differ statistically from each other. Uppercases letters compare substrates and lowercase letters compare temperatures, by Tukey's test at $\mathrm{P}<0.05$.

should read:

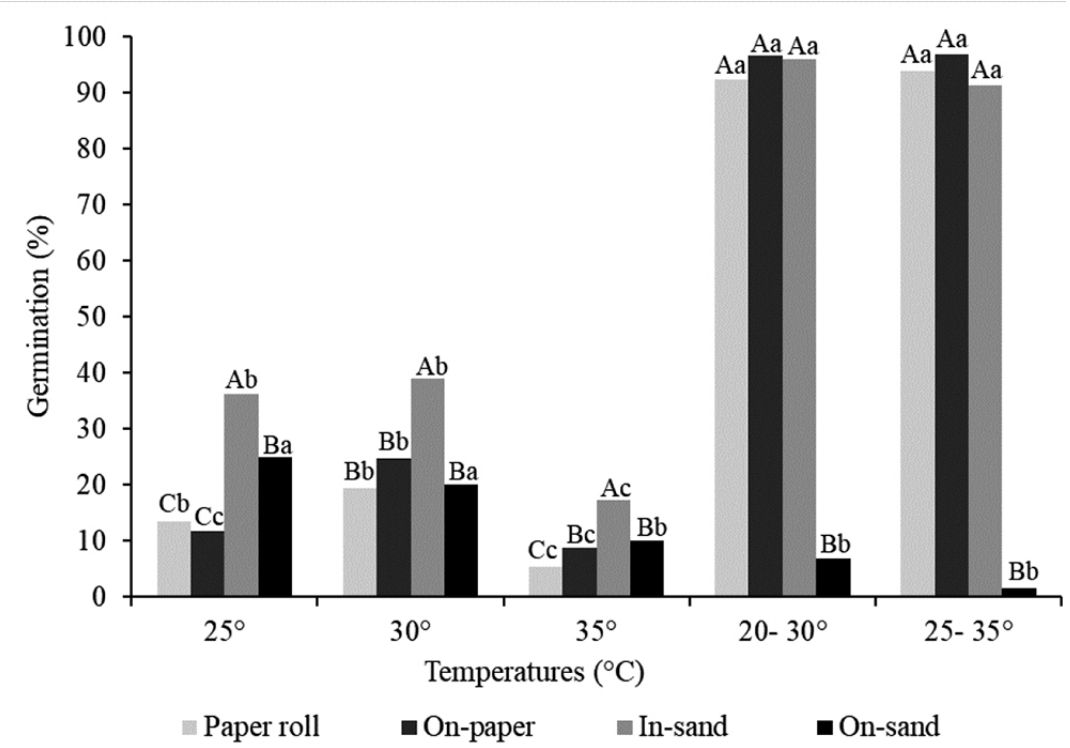

Figure 1. Germination (\%) of guava seeds as a function of temperatures and substrates. -Means followed by the same letter do not differ statistically from each other. Uppercases letters compare substrates and lowercase letters compare temperatures, by Tukey's test at $\mathrm{P}<0.05$. 